\title{
A RHEUMATOID SYNDROME OCCURRING IN THE ELDERLY
}

\author{
BY \\ L. BAGRATUNI \\ Department of Clinical Biochemistry, Radcliffe Infirmary, Oxford
}

(RECEIVED FOR PUBLICATION FEBRUARY 16, 1953)

The classification and nomenclature of disease is an arbitrary procedure depending on the maximum number of constant symptoms and signs falling together frequently enough to form a recognizable pattern. The pursuit of the classical manifestations of any disease often blinds clinicians to numerous atypical but related forms. This paper presents a syndrome probably allied to rheumatoid arthritis but not generally recognized.

It occurs in middle aged and elderly people, presenting essentially as a pyrexia of unknown origin. There is initial general malaise, and loss of appetite and weight, with an intermittent pyrexia reaching at times to $103^{\circ} \mathrm{F}$. or higher. With these symptoms there is a vague generalized ache confined most often to the shoulders and cervical region, but sometimes involving the rest of the spine and back, chest, abdomen, and limbs. Movements of the affected joints are performed with difficulty, but the movements are full and the limitation is usually due to discomfort. There is no swelling or redness of the joints. The chest pains may be sharp or aching but are rarely pleuritic. There may be episodes of diarrhoea and vomiting, conjunctivitis, and erythematous rashes.

A profound constitutional disturbance is shown by the persistent fever, anaemia, and loss of weight. Examination may reveal some lymph-node enlargement with or without splenomegaly. Usually, however, on clinical examination, nothing abnormal can be found apart from the fever, tachycardia, and occasional tenderness to pressure over the painful areas.

Special investigations show the blood sedimentation rate to be extremely high, usually well over $100 \mathrm{~mm}$./hr, and often reaching $130 \mathrm{~mm}$./hr. This is a most characteristic finding. The haemoglobin falls because of a secondary iron-resistant anaemia. The white blood count may be raised with a polymorphonuclear leucocytosis often associated with a lymphocytosis. Türck cells may appear in the peri户 pheral blood, or there may be a mild eosinophiliai In severe cases leucopenia develops. The blood albumin/globulin ratio is altered, with a fall in the albumin and an occasional rise in the globulin? Sometimes there is a reversal of the ratio. The bloot fibrinogen is invariably raised, often to figures $a \bar{c}$ high as $900 \mathrm{mg}$. per cent. The bone marrow rarely shows any significant or characteristic abnormality but there may be an increase in plasma cells to the upper limits of normal, some of the forms being atypical.

Chest $x$ rays may show vague transient shadow and opacities, and the skeletal system some degree of de-calcification. Blood cultures and agglutination\& are negative. In typical cases of the syndrome th $\overrightarrow{\widehat{S}}$ joints show no radiological change, but cases have been included with osteo-arthritic change, and these form transitional types towards true rheumatoi arthritis. The ultimate prognosis is good, but the disease may run a long course of months or years.

\section{Case Reports}

Case 1. A 62-year-old farmer was admitted to the Radcliffe Infirmary on May 19, 1944, under Professof L. J. Witts. He had not felt really well since a totab dental extraction 6 years previously. In August, 1943, he had noticed that he was losing energy, feeling cold an shivery, and on occasions sweating profusely. In Novemo ber he had been admitted to a nursing home with ano intermittent fever and an erythrocyte sedimentation rati of $143 \mathrm{~mm}$./hr (Westergren). Agglutinations to $\mathrm{Sa} \omega$ monella and Brucella organisms as well as blood cultuce had been negative. At that time he developed mild stiffs ness and discomfort around the neck and shoulders fot the first time. $X$ ray of the cervical spine showed mino osteo-arthritic changes. In December he developed "rheumatic" pains in his hands. By March, 1944, he had improved considerably, but on admission his previous symptoms were exacerbated, and he had vomited sis times. 
He had been a farmer in Australia between 1910-1916 but had had to leave the country because of attacks of dysentery. He had been well up to the time of his tooth extractions, but from time to time had had attacks of conjunctivitis.

Examination.-He was very thin. Temperature $99 \cdot 6^{\circ}$ F.; pulse 108; respiration 20; blood pressure 110/65. There was limitation of movement of the cervical spine, but all other joint movements were good. Moderate axillary lymph node enlargement. Spleen not palpable. Other systems natural.

Erythrocyte sedimentation rate $61 \mathrm{~mm}$./hr (Wintrobe).

White blood count 3,000, 42 per cent. polymorphs, haematocrit 32 per cent., colour index 0.97 , blood plasma uric acid $1.73 \mathrm{mg}$. per cent.

Total plasma proteins, $7 \cdot 2 \mathrm{~g}$. per cent., albumin $2 \cdot 7 \mathrm{~g}$. per cent., globulin $4 \cdot 1 \mathrm{~g}$. per cent., fibrinogen $719 \mathrm{mg}$. per cent.

Takata Ara strongly positive.

$X$ ray of cervical spine showed new bone formation between atlas and occiput, but no evidence of ankylosing spondylitis.

Sternal puncture showed a poorly cellular marrow with a small proportion of cells resembling myeloma cells.

It was considered that he had myelomatosis. Throughout his stay in hospital he ran a low grade fever which did not respond to any therapy.

Therapy.-He was discharged after transfusion of one pint of blood.

Later Developments.-On June 23, 1944, he was readmitted for repetition of the tests, and was found to have improved. The backache was less severe and had moved to the lumbar region. Sternal puncture did not confirm a diagnosis of myelomatosis. Bone $x$ rays revealed no abnormality. The albumin/globulin ratio remained reversed.

In November, 1945, he was re-admitted with fever, backache, and a dry cough. There was now slight limitation of wrist extension and shoulder movement, but no gross changes could be observed.

Erythrocyte sedimentation rate $75 \mathrm{~mm}$./ hr (Westergren).

Haemoglobin 66 per cent.

Albumin/globulin ratio reversed.

Fibrinogen $1.003 \mathrm{mg}$. per cent. There was a trace of albumin in the urine but no Bence Jones protein.

$X$ ray of the chest revealed a small round opacity at the left base of undetermined nature.

He continued to run a fever up to $102 \cdot 8^{\circ} \mathrm{F}$. and a tachycardia between 100-120. He received a transfusion of two pints of blood and was discharged unimproved, but at home he once again felt better.

On March 15, 1950, at the age of 68 he was re-admitted under the care of Dr. A. M. Cooke for the fourth time, complaining of similar indefinite symptoms. He had signs of chronic bronchitis in his chest.

Erythrocyte sedimentation rate $130 \mathrm{~mm}$./hr (Westergren).
Haemoglobin 70 per cent.

White blood count 3.200 with neutropenia and a proportion of Türck cells.

Wassermann reaction negative.

Agglutinations to Salmonella. Brucella, and Leptospira organisms negative.

Albumin/globulin ratio remained reversed.

Electrocardiogram showed a sinus tachycardia of 110 . Urine contained protein and granular and cellular casts.

Salicylates, chloramphenicol, and aureomycin had no effect on the fever which rose to $102^{\circ} \mathrm{F}$. Chest $x$ ray showed a diffuse increase in lung markings suggesting infiltration rather than congestion since there was no increase in heart size. $X$ rays of the hands revealed mild decalcification only. On April 15, 1950, he was discharged home unchanged.

Once more he improved, and when last heard of was well, apart from osteo-arthritis of the spine. His disease had persisted with remissions for 12 years.

Case 2. A 57-year-old housewife was admitted to the Radcliffe Infirmary on February 6, 1952, under Dr. F. G. Hobson. She complained of a generalized diffuse ache in her back, shoulders, and chest for the previous 5 years. The symptoms had gradually developed after partial thyroidectomy for nodular goitre. This had not been toxic. For the year before admission she had had attacks of fever and sweating and had lost 4 stone in weight. She had paraesthesiae in her arms, vague abdominal discomfort with flatulence, and before admission an attack of vomiting and diarrhoea for which no cause: could be found. On one occasion she had had an erythematous rash over her shoulders. For the previous. few months she had had a dry cough.

Examination.-She looked reasonably well. Temperature $98 \cdot 6^{\circ} \mathrm{F}$; pulse 100 ; blood pressure $120 / 75$. There was discomfort in the cervical region on rotating the neck, but all movements were full and other joints were natural. There was tenderness over the eighth and ninth ribs antero-laterally. Liver edge just palpable. Tongue red and smooth. Short apical systolic murmur. Other systems natural.

Erythrocyte sedimentation rate $113 \mathrm{~mm}$./hr (Westergren).

Haemoglobin 83 per cent.

White blood count 7,300.

Total plasma proteins $6 \cdot 3 \mathrm{~g}$. per cent., albumin $3 \cdot 2 \mathrm{~g}$. per cent., globulin $2 \cdot 2 \mathrm{~g}$. per cent., fibrinogen $857 \mathrm{mg}$. per cent.

Marrow puncture normal.

Urine normal.

Chest $x$ ray showed well-healed infiltration of apices and a small opacity at the left apex whose nature was not determined.

Barium meal and cholecystogram normal.

Agglutinations to Salmonella and Brucella organisms negative.

Blood culture grew Streptococcus faecalis, probably a contaminant.

After 6 weeks the fever gradually settled and the erythrocyte sedimentation rate fell to $65 \mathrm{~mm}$. $/ \mathrm{hr}$. 
Therapy.-A pneumoperitoneum had been induced in case there should be pus under the diaphragm, but this only revealed a spleen double the normal size on screening. No treatment had any effect on the course of her illness. She improved and gained weight and lost her aches and pains. When seen in out-patients on May 2, 1952, she was much better but had pains below her sternum and over the left ilium. Haemoglobin 82 per cent., erythrocyte sedimentation rate $69 \mathrm{~mm}$. $/ \mathrm{hr}$ (Westergren). Repeated sputum examination revealed no tubercle bacilli. The duration of her illness had been over 5 years.

The Figure shows her temperature, pulse rate, and erythrocyte sedimentation rate during her stay in hospital.
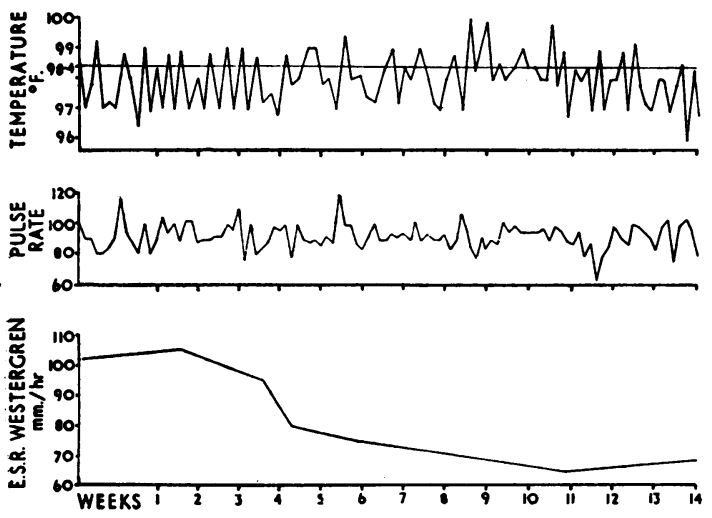

FiguRE.-Case 2. Temperature, pulse, and sedimentation rate.

Case 3. A 73-year-old gardener was admitted to the Radcliffe Infirmary under Dr. F. G. Hobson on February 2 , 1951, with 6 weeks' history of headaches, cough, loss of weight, and pallor. He was found to have mild heart failure, liver enlargement, ankle oedema, and signs of broncho-pneumonia. The chest infection responded well to streptomycin and the oedema subsided with rest in bed, but he continued to run a fever up to $100^{\circ} \mathrm{F}$.

Erythrocyte sedimentation rate $112 \mathrm{~mm}$./ hr (Westergren).

Haemoglobin 80 per cent.

White blood count 12,000 .

Total plasma proteins $5.7 \mathrm{~g}$. per cent., albumin $3.0 \mathrm{~g}$. per cent.. globulin and fibrinogen $2 \cdot 7 \mathrm{~g}$. per cent.

Thymol turbidity and colloidal gold tests negative.

Wassermann reaction negative.

Sternal puncture revealed normal marrow with 5.6 per cent. plasma cells.

The anaemia was resistant to iron and the haemoglobin fell to 63 per cent. He was discharged, and when seen in out-patients a month later was complaining of stiffness in the hands, wrists, back, hips, and knees. Externally there was no obvious abnormality or limitation of movement. $X$ ray of the left hand showed mild decalcification with osteo-arthritic changes in some of the joints. Erythrocyte sedimentation rate $112 \mathrm{~mm}$. $/ \mathrm{hr}$ (Westergren).
Physiotherapy gave no relief. On his last visit 魚 erythrocyte sedimentation rate was $104 \mathrm{~mm}$. $/ \mathrm{hr}$ (Westengren), and he was having persistent pain in the backs both thighs. He had been unwell for 2 years.

Case 4. A 62-year-old widow was admitted to Radcliffe Infirmary under Professor L. J. Witts $\overline{\text { Gn }}$ July 12,1941 , complaining of vague aches in the shogders, arms, neck, and lumbar region for the previogs year. She felt weak and short of breath and had last 4-5 stone over this period.

Examination.-She was pale and thin.

Temperature $100^{\circ} \mathrm{F}$; ; pulse 120 ; blood pressuure $140 / 80$. There was a harsh apical systolic murmur ahd scattered rhonchi in her chest. Cervical lymph nofes slightly enlarged. Spleen not palpable. Other systems normal.

Erythrocyte sedimentation rate $67 \mathrm{~mm} . / \mathrm{hr}$ (Westẹgren).

Haemoglobin 40 per cent.

White blood count $7,800,72$ per cent. neutrophils, 21 per cent. lymphocytes, 5 per cent. monocytes, haematocrit 26 per cent.

Marrow puncture revealed a few atypical plasma cens.

Small quantities of occult blood found in stools.

Gastroscopy showed atrophic mucosa with a haemonrhagic patch.

She ran a low grade fever throughout her stay on hospital. She was discharged but had to be re-admittisd because of exacerbation of symptoms. The ache in the shoulders, back, and hips had increased, and there limitation of movement due to pain.

Erythrocyte sedimentation rate $148 \mathrm{~mm}$./ hr (Weste gren).

Haemoglobin 40 per cent.

In view of the presence of occult blood it was thoug that she might have an abdominal neoplasm. Sigmoidsscopy revealed only an ulcerated pile and a laparotomy performed by Mr. Elliot-Smith showed no abnormaliti. A skin biopsy taken at this time was normal. $X$ ray of her right shoulder showed marked osteo-arthritis. Afier the operation her aches gradually returned and she comtinued to run a fever with tachycardia. She was discharged unimproved and undiagnosed.

She had been unwell for nearly 2 years.

Case 5. A 58-year-old medical practitioner was seen Dr. A. M. Cooke in August, 1943, on account of lassitude and generalized aches and pains, chiefly in the lims, which had come on over the previous year. The pams were in the muscles rather than the bones.

Erythrocyte sedimentation rate $28 \mathrm{~mm}$./ hr (Westegren).

Haemoglobin 80 per cent.

Blood pressure 120/80.

$X$ ray of the spine showed a crack in C 6, perhaps dge to a recent fall, and some osteo-arthritis. Physig̈l examination revealed no abnormality.

He continued to feel ill and lost 3 stone over 5 yea 
Professor A. W. M. Ellis saw him a few months later because of flatulence and indigestion.

A barium meal showed no lesion.

Erythrocyte sedimentation rate $110 \mathrm{~mm}$./hr (Westergren).

Haemoglobin 75 per cent.

White blood count 9,000 , eosinophils 720 .

He had had bouts of fever and sweating. The pains were now chiefly in the deltoids and lumbar region. Periodic examinations revealed no obvious abnormality. A cholecystogram was normal. Urine contained occasional traces of albumin. He gradually improved after a while, and by March, 1945, was much better. When last seen in September, 1951, he looked and felt well, although he had occasional twinges of pain.

His illness had lasted 3 years.

Case 6. A 64-year-old widow was admitted to the Radcliffe Infirmary on April 16, 1952, under Dr. F. G. Hobson. For 7 weeks she had had pains in the backs of both thighs, cervical spine, and shoulders. She had felt generally unwell with fever and sweating and had lost weight. There had been no joint swelling. Massage, codeine, penicillin, and salicylates had no effect and she had become worse.

Examination.-She was thin and pale. Temperature $99^{\circ} \mathrm{F}$; pulse 88 ; blood pressure $150 / 90$. There was considerable wasting of both thighs and triceps, but the joints were normal and allowed full range of movement. She was tender over the hamstring muscles. No nodules could be found. Slight cervical lymph node enlargement and thyroid a little full. Apart from a slight kyphosis other systems were normal.

Erythrocyte sedimentation rate $100 \mathrm{~mm}$./ hr (Westergren).

Haemoglobin 86 per cent.

White blood count 6,050 .

Total plasma proteins $7 \cdot 3 \mathrm{~g}$. per cent., albumin $3 \cdot 9 \mathrm{~g}$. per cent., globulin $2 \cdot 6$ g. per cent., fibrinogen $621 \mathrm{mg}$. per cent.

After a few days salicylates seemed to control the fever, which rose when they were discontinued. The second time they were tried it took 9 days for the fever to settle. The muscle pains improved, but she continued to lose weight. At no time was there a pronounced tachycardia.

Chest $x$ ray was clear and $x$ rays of the hands and knees were normal.

Urine natural.

By June 5, 1952, the erythrocyte sedimentation rate had fallen to $52 \mathrm{~mm}$. $/ \mathrm{hr}$ (Westergren), and the temperature had settled to $99^{\circ} \mathrm{F}$.

Agglutinations to Salmonella and Brucella organisms negative.

After 2 months in hospital she was discharged, gaining weight and symptomless.

Case 7. A 68-year-old statistical worker was admitted to the Radcliffe Infirmary under Dr. A. M. Cooke on August 9, 1943. For 7 weeks he had suffered from night sweats and severe vertical headaches on the right and left sides. For about the same period he had experienced severe lumbar backache and for 4 weeks a weakness of both legs when attempting to walk. This was a soreness rather than pain. Over this period he had vomited several times and had been constipated. Many years previously he had had jaundice, cervical adenitis, and peritonitis following appendicectomy. There was no family history of rheumatism.

Examination.-He was very thin. Temperature $99 \cdot 2^{\circ}$ F.; pulse 74 ; respiration 20 ; blood pressure $125 / 75$. There was no abnormality of the cardiovascular, respiratory or alimentary systems. There was a generalized stiffness of both legs, but the reflexes were normal.

Erythrocyte sedimentation rate $107 \mathrm{~mm}$./ hr (Westergren).

Haemoglobin 70 per cent.

White blood count 16,000 , neutrophils 11,680 , eosinophils 160 , lymphocytes 3,360 , monocytes 800 .

Lumbar puncture and C.S.F. normal.

Chest $x$ ray showed a raised right diaphragm with adhesions at both bases.

Skull $x$ ray, spine $x$ ray, barium meal, barium enema, and intravenous pyelogram normal.

Wassermann reaction negative.

Blood urea $30 \mathrm{mg}$. per cent. Total plasma proteins $7 \cdot 0$ g. per cent., albumin $4 \cdot 4$ g. per cent.. globulin and fibrinogen $2.6 \mathrm{~g}$. pet cent. Plasma uric acid $2 \cdot 1 \mathrm{mg}$. per cent.

Occult blood present in very small amounts.

During his stay in hospital he ran a slight pyrexia with the pulse rate between 70 and 90 . He gained weight and improved. On August 31, 1943, he was discharged much improved. At follow-up on November 22, 1944, he was complaining of rheumatic pains in the buttocks and thighs, which on examination were wasted. There was no evidence of temporal arteritis, and the erythrocyte sedimentation rate was $28 \mathrm{~mm}$. $/ \mathrm{hr}$ (Westergren).

\section{Discussion}

The syndrome here described resembles the prodromal stage of rheumatoid arthritis before the joint lesions have become established. The other collagen diseases may also present with similar prodromal symptoms, but in typical cases the pattern of the disease quickly becomes established.

Atypical manifestations of rheumatoid arthritis were stressed by Ropes and Bauer (1945); Ellman and Ball (1948) described three cases of rheumatoid disease with joint, lung, and heart involvement; Bywaters (1949) described a variant of rheumatoid arthritis resembling palindromic rheumatism; Littler (1951) studied a remarkable case with Felty's and Sjögren's syndrome associated with signs of mitral stenosis not due to rheumatic fever; post-mortem studies by Baggenstoss and Rosenberg (1943) revealed the generalized nature of rheumatoid arthritis with visceral involvement; Leichtentritt (1943) 
showed the lesion in peripheral nerves; the characteristic tendon changes were described by Kellgren and Ball (1950).

As Duff (1948) has pointed out, the characteristic change in all diseases of the collagen system is fibrinoid change followed by connective tissue proliferation. The degree of each varies according to the disease. In rheumatic fever and rheumatoid arthritis the fibrinoid necrosis is overshadowed by a proliferative and inflammatory response; in disseminated lupus erythematosus the fibrinoid change predominates; in periarteritis nodosa the adventitia of the small vessels proliferates while the fibrinoid change is reserved for the media and intima; in scleroderma the proliferation of collagen is so overwhelming that it is only with difficulty that patches of fibrinoid change can be found in the walls of small vessels. Although these diseases are usually clear entities, atypical forms have been described in which features of several may be present together (Banks, 1941). Similarly, Bevans (1945) described two cases of scleroderma with "wireloop" kidney lesions similar to those found in disseminated lupus erythematosus.

To add to the difficulties of diagnosis, disseminated lupus erythematosus may present without cutaneous manifestations (Rakov and Taylor, 1942). Rheumatoid arthritis and rheumatic fever resemble each other more than they do the other collagen diseases in that they show the characteristic rheumatoid nodule. Intermediate types may occur however. Rosenberg and others (1943) found sixteen cases of heart lesions indistinguishable from rheumatic heart disease in thirty post-mortem examinations of patients with rheumatoid arthritis. Furthermore, Friedberg and Gross (1934) described four cases of rheumatic fever with lesions typical of periarteritis nodosa. These similarities and differences have been discussed by Dawson and Tyson (1936).

Kellgren (1952) suggested that in rheumatoid disease there is a breaking up of the collagenpolysaccharide connective tissue complex, the collagen disintegrating into peptides which diffuse out and promote an inflammatory response. Menkin (1947) has similarly postulated the breakdown of protein to peptides which initiate the normal inflammatory response and has fractionated these. The tissue which remains after the collagen disintegration is rich in polysaccharides and produces fibrinoid change by replacing the damaged tissue. That connective tissue change may occur at the molecular level without microscopic evidence is suggested by the case of a boy who died of scleroderma but whose tissues showed no histological change (MacCallum, 1926).
These atypical forms are stressed because they reveal the confusing clinical and pathologicat picture which the collagen diseases may present, the typical symptoms appearing to mimic each other $\overrightarrow{\vec{\xi}}$

The syndrome here described approximates more closely to rheumatoid arthritis than to the othescollagen diseases on account of the long course $\frac{\bar{y}}{\overline{0}}$ muscle wasting, fever, anaemia, good prognosis, and joint involvement which occurs in transitional types This, however, was rarely gross either clinically op radiologically except in Case 1 . The most character $\overrightarrow{0}$ istic feature of the syndrome is the diffuse ache roundthe shoulders and cervical region, at times involving also the back, chest, and limbs. In those cases without joint involvement it must be postulated tha $\bar{p}$ there is a generalized alteration in the connectiv $\vec{v}$ tissue, and where the change occurs in fascial planes or muscles there is pain and discomfort. If there iso peripheral nerve involvement there may be paro aesthesia. Albuminuria may result from the non-specific glomerulo-nephritis so frequently found by Baggenstoss and Rosenberg (1943). Four of the्ष cases had flatulence and abdominal discomfort Three had spells of diarrhoea and vomiting fors no apparent cause. It is perhaps significant that, in the thirty post-mortem examinations of Rosenberg and others (1943), two patients had died of pros longed diarrhoea of undetermined aetiology.

The transient opacities in the chest seen in thळ్ radiographs may have been due to involvement of the lungs by the rheumatic process; it was clinicall $\overrightarrow{5}$ manifest by an unproductive cough.

In no case was there any evidence of ankylosing spondylitis and the significance of the osteo-arthritie. changes was difficult to interpret in view of the age of the patients.

The lupus erythematosus test of Haserick (1945) was attempted in Case 2 with negative results. Ther was no evidence of lupus erythematosus cells in the four cases where a marrow puncture was done, but atypical plasma cells were seen twice and the count was a high normal once. The significance of this is obscure, but in general plasma cells proliferate in? association with a rise in the globulin (Barr, 1950). Irf the cases reported, there was no gross alteration in the globulin except in Case 1, but the albumin was low except in Case 7. The high blood fibrinogen prow bably accounted for the raised sedimentation rate.

In no case was there any evidence of mitraf? stenosis. The illness may last for several years wit| remissions, but the ultimate prognosis is good:+ Salicylates were only partially effective in Case $6{ }^{\circ}$ in the others they had no effect at all.

The term "rheumatoid" disease should be more? extensively used to describe this and similar syn@ 
TABLE

\begin{tabular}{|c|c|c|c|c|c|c|c|c|c|c|}
\hline Case & No. & . &.. & 1 & 2 & 3 & 4 & 5 & 6 & 7 \\
\hline Age a & nd sex & $\cdots$ & $\ldots$ & 62 \% & 57 우 & $73 \sigma$ & $62 \%$ & 58 वै & $64 \%$ & 68 ๙ \\
\hline \multirow{7}{*}{$\begin{array}{c}\text { Pain } \\
\text { in }\end{array}$} & \multicolumn{3}{|c|}{ Shoulder girdle } & $\div+$ & ++ & ++ & ++ & + & ++ & - \\
\hline & \multicolumn{3}{|c|}{ Cervical spine .. } & ++ & ++ & +1 & ++ & + & ++ & - \\
\hline & \multicolumn{3}{|c|}{ Lumbar spine .. } & ++ & + & $\div$ & + & + & - & + \\
\hline & \multicolumn{2}{|c|}{ Other joints } & $\cdots$ & Wrists & - & $\begin{array}{l}\text { Hands, wrists, } \\
\text { hips, knees }\end{array}$ & Hips & - & - & - \\
\hline & \multicolumn{2}{|l|}{ Muscle } & . & - & Arms & $\begin{array}{l}\text { Arms, } \\
\text { thighs }\end{array}$ & Arms & $\begin{array}{l}\text { Arms, } \\
\text { thighs }\end{array}$ & Thighs & $\begin{array}{l}\text { Thighs. } \\
\text { buttocks }\end{array}$ \\
\hline & Chest & .. & . & - & + & - & + & + & - & 一 \\
\hline & \multicolumn{2}{|c|}{ Abdomen } & $\cdots$ & Flatulence & Flatulence & Flatulence & $\begin{array}{l}\text { Pain in } \\
\text { right iliac fossa }\end{array}$ & Flatulence & - & - \\
\hline \multicolumn{2}{|c|}{ Joint swelling } & $\cdots$ & $\cdots$ & - & 一 & Right wrist & - & - & - & 一 \\
\hline \multicolumn{2}{|c|}{ Weight loss } & $\cdots$ & $\cdots$ & ++ & ++ & ++ & ++ & ++ & ++ & ++ \\
\hline \multicolumn{3}{|c|}{ Fever and sweating } & $\cdots$ & +- & ++ & $+\div$ & ++ & ++ & ++ & ++ \\
\hline \multicolumn{2}{|c|}{ Dry cough } & $\cdots$ & $\cdots$ & - & + & + & - & 一 & 一 & - \\
\hline \multicolumn{4}{|c|}{ Rash or conjunctivitis } & - & + & - & - & - & - & - \\
\hline \multicolumn{4}{|c|}{$\begin{array}{cll}\text { Lymph node enlarge- } \\
\text { ment }\end{array}$} & + & + & - & $-\dot{1}$ & - & + & 一 \\
\hline \multicolumn{2}{|c|}{ Splenomegaly } & $\cdots$ & $\cdots$ & - & + & - & - & - & - & - \\
\hline \multicolumn{4}{|c|}{ Vomiting and diarrhoea } & - & ++ & + & - & - & - & Vomiting \\
\hline \multicolumn{4}{|c|}{$\begin{array}{l}\text { Erythrocyte sedimenta- } \\
\text { tion rate (highest) } \ldots \\
\end{array}$} & 145 & 105 & 112 & 148 & 118 & 100 & 107 \\
\hline \multicolumn{4}{|c|}{$\begin{array}{c}\text { Haemoglobin } \\
\text { (per cent.) }\end{array}$} & 50 & 78 & 63 & 40 & 70 & 81 & 70 \\
\hline \multicolumn{3}{|c|}{ White blood cells } & $\cdots$ & $\begin{array}{l}\text { Türck cells } \\
\text { Leucopenia }\end{array}$ & Leucocytosis & Leucocytosis & Normal & $\begin{array}{l}\text { Eosinophilia } \\
\text { Leucocytosis }\end{array}$ & Leucocytosis & Leucocytosis \\
\hline \multicolumn{2}{|c|}{ Bone marrow } & .. & .. & $\begin{array}{c}\text { Atypical } \\
\text { plasma cells }\end{array}$ & Normal & $\begin{array}{l}5.6 \text { per cent. } \\
\text { plasma cells }\end{array}$ & $\begin{array}{c}\text { Atypical } \\
\text { plasma cells }\end{array}$ & - & - & - \\
\hline \multicolumn{4}{|c|}{ Albumin/Globulin ratio } & $2 \cdot 2: 4 \cdot 6$ & $3 \cdot 3: 2 \cdot 6$ & $3 \cdot 0: 2 \cdot 7$ & 一 & - & $3 \cdot 9: 2 \cdot 6$ & $4 \cdot 4: 2 \cdot 6$ \\
\hline \multicolumn{2}{|c|}{ Fibrinogen } & $\cdots$ & $\cdots$ & 1,003 & 831 & 一 & - & - & 778 & - \\
\hline Urine & $\cdots$ & $\cdots$ & $\cdots$ & Casts, Protein & Normal & Normal & Normal & Protein & Normal & Normal \\
\hline \multirow{2}{*}{$\mathrm{X}$ ray } & Chest & $\cdots$ & $\cdots$ & Vague shadows & Vague shadows & Normal & Normal & Normal & Normal & Basal adhesions \\
\hline & Joint & $\cdots$ & $\cdots$ & $\begin{array}{c}\text { Cervical } \\
\text { osteo-arthritis }\end{array}$ & Normal & $\begin{array}{l}\text { Osteo-arthritis } \\
\text { left hand, mild } \\
\text { decalcification }\end{array}$ & $\begin{array}{l}\text { Osteo-arthritis } \\
\text { right shoulder }\end{array}$ & $\begin{array}{l}\text { Osteo-arthritis } \\
\text { cervical spine }\end{array}$ & Normal & Normal \\
\hline \multicolumn{4}{|c|}{$\begin{array}{c}\text { Duration with } \\
\text { sions (years) }\end{array}$} & 12 & $5+$ & $2+$ & 2 & 3 & 2 months + & $1 \div$ \\
\hline
\end{tabular}

dromes. Some of the periodic fevers described by Reimann (1951) may well be examples of a similar disease process. So far no post-mortem studies of this syndrome have been available and a skin biopsy from Case 2 revealed no abnormality. All the cases described were undiagnosed and discharged as pyrexias of unknown origin. Perhaps if this syndrome is recognized it will save numerous unnecessary investigations being performed on repeated admissions in an effort to reach a simple diagnosis.

The accompanying Table summarizes the main findings.

\section{Addendum}

After I had submitted this paper for publication, my attention was drawn to a communication by Kersley (1951) on a related myalgic syndrome of acute onset and crippling severity. Thirteen patients, of average age 71 , had widespread pain and tenderness of muscles, and a high blood sedimentation rate; three of them developed slight swellings in the hands or knees. Muscle biopsies on four patients were normal. Three patients treated with ACTH or cortisone responded well, but in others the condition tended to become chronic. In several cases the syndrome 
followed stress; it appears to fit in well between the syndrome described above and true rheumatoid arthritis.

\section{Summary}

A syndrome is described affecting elderly people and characterized by generalized aching, especially of the shoulders and cervical region, but often also involving the back, chest, and limbs. There is a prolonged intermittent fever with sweating and great loss of weight. The sedimentation rate is very high and there is a secondary anaemia. The joints need not be involved. The course may be prolonged over months or years, but the ultimate prognosis is good.

The syndrome is more closely related to rheumatoid arthritis than to the other collagen diseases. It is suggested that the term rheumatoid disease be more extensively used to describe this and similar syndromes.

I should like to thank Professor L. J. Witts, Dr. F. G. Hobson, and Dr. A. M. Cooke for permission to publish details of the cases which were under their care. I should also like to thank them and Mr. J. R. P. O'Brien for helpful criticism, and the Biochemistry and Pathological Departments for those investigations which were not carried out by myself.

\section{REFERENCES}

Baggenstoss, A. H., and Rosenberg, E. F. (1943). Arch. Path., Chicago, 35, 503 .

Banks, B. M. (1941). New Engl. J. Med., 225, 433.

Barr, D. P. (1950). Amer. J. Med., 9, 277.

Bevans, M. (1945). Amer. J. Path., 21, 25.

Bywaters, E. G. L. (1949). Annals of the Rheumatic Diseases, 8, 1.

Dawson, M. H., and Tyson, T. L. (1936). J. Lab. clin. Med., 21, 575.

Duff, G. L. (1948). Canad. med. Ass. J., 58, 317.

Ellman, P., and Ball, R. E. (1948). Brit. med. J., 2, 816.

Friedberg, C. K., and Gross, L. (1934). Arch. intern. Med., 54, 170

Haserick, J. R. (1951). J. Amer. med. Ass. 146, 16.

Kellgren, J. H. (1952). Brit. med. J., 1, 1093 and 1152.

-, and Ball, J. (1950). Annals of the Rheumatic Diseases, 9, 48. Kersley, G. D. (1951). “Proc. II Cong. Europ. Reum., Barcelona,

Leichtentritt, B. (1943). Ann. intern. Med., 19, 116.

Littler, T. R. (1951). Annals of the Rheumatic Diseases, 10, 405

MacCallum, W. G. (1926). Trans. Ass. Amer. Phys., 41, 190.

MacCallum, W. G. (1926). Trans. Ass. Amer. Phys., 41, 190.

Menkin, V.'(1947). I.nncet, 1, 660.

Rakov, R. L., and Tavlor, J. S. (1942). Arch. intern. Med., 70, 88.

Reimann, H. A. (1951). Medicine, B.litimore, 30, 219.

Ropes, M. W., and Bauer, W. (1945). New Engl. J. Med., 233, 592,618 .

Rosenberg, E. F., Baggenstoss, A. H., and Hench, P. S. (1943) Ann. intern. Med., 19, 114.

Syndrome rhumatoide survenant chez des vieillards

\section{RÉSUMÉ}

On décrit un syndrome atteignant les vieillards et ${ }_{-}^{\circ}$ caractérisé par une douleur généralisée, surtout accentuée $\vec{H}$ aux épaules et dans la région cervicale mais s'étendant $\omega$ souvent au dos, à la poitrine et aux extrémités. On notẹ une fièvre intermittente et prolongée, avec des sueursō et un amaigrissement marqué. La sédimentation globulaire est très rapide et il y a une anémie secondaire. $N$ L'atteinte articulaire n'est pas de règle. La maladie peut: évoluer pendant des mois et des années, mais le pronostic $\infty$ ultérieur est bon.

$\mathrm{Ce}$ syndrome est plus étroitement lié à l'arthrite rhumatismale qu'aux autres maladies collagènes. On ${ }^{-}$ suggère l'emploi plus fréquent du terme "maladie rhumatoide" pour désigner ce genre de syndromes.

Síndrome reumatoide ocurriendo en los ancianos Sumario

Se describe un síndrome que ocurre en los ancianos y que se caracteriza por un dolor generalizado, particularmente de la espalda y de la región cervical, extendiéndose a menudo al dorso, al pecho y a laso extremidades. Se nota una fiebre intermitente y pro- $ڤ$ longada, con sudores y un adelgazamiento pronunciado. D La sedimentación globular es muy rápida y hay anemia secundaria. No hay necesariamente implicación articular. La enfermedad puede prolongarse durante meses $o$ años, $\exists$ pero el pronóstico ulterior es bueno.

Este síndrome está más estrechamente relacionado conö la artritis reumatoide que con las demás enfermedades colágenas. Se sugiere el empleo más extendido del término "enfermedad reumatoide" para describir este. síndrome y otros del tipo similar. 